\title{
SPERM NUMBERS AND FERTILIZATION IN THE RABBIT
}

\author{
J. W. OVERSTREET \\ A.R.C. Unit of Reproductive Physiology and Biochemistry,* \\ University of Cambridge
}

(Received 9th Fanuary 1969)

\begin{abstract}
Summary. Groups of does were tubally inseminated with concentrations of 500 to 10,000 motile capacitated spermatozoa in $10 \mu \mathrm{l}$ of serum acidic saline about the time of ovulation, or with 1000 to 10,000 motile untreated spermatozoa $10 \mathrm{hr}$ before the expected time of ovulation. The minimum number of spermatozoa required for fertilization was in the 500 to 1500 range. Fertilization levels $>90 \%$ were not reached until 10,000 motile capacitated spermatozoa were inseminated at the time of ovulation, while 10,000 untreated spermatozoa deposited $10 \mathrm{hr}$ earlier, fertilized less than $70 \%$ of the eggs.

A higher level of fertilization was consistently observed when the spermatozoa were inseminated in $10-\mu l$ volumes than when the same number of spermatozoa was deposited in $100 \mu$ l. There was little difference in the level of fertilization irrespective of whether tubal insemination of capacitated spermatozoa took place about the time of, or $4 \mathrm{hr}$ before, ovulation.
\end{abstract}

\section{INTRODUCTION}

At the time of ovulation, it has been estimated that 2000 to 5000 spermatozoa are present in the entire Fallopian tubes of the naturally mated rabbit (Austin, 1948; Chang, 195la; Braden, 1953). Braden (1953) suggested that the cervix, utero-tubal junction and isthmus of the Fallopian tube act as barriers to sperm ascent, thereby restricting massive sperm migration from the vagina so that less than 500 spermatozoa may reach the site of fertilization.

In previous investigations involving the deposition of spermatozoa in the Fallopian tubes, the numbers used have generally been in excess of postulated physiological levels, and fertilization levels observed under these conditions have seldom exceeded $70 \%$ to $80 \%$ (Chang, 1951b, 1957, 1958; Noyes, Walton \& Adams, 1958; Adams \& Chang, 1962; Dukelow, Chernoff \& Williams, 1967). Tubal insemination of up to $2 \times 10^{6}$ capacitated spermatozoa may still result in less than $50 \%$ fertilization of recovered eggs (Hamner \& Sojka, 1967; Hamner, Jones \& Sojka, 1968). Austin (1948) deposited $2 \times 10^{6}$ epididymal spermatozoa into the tubes 5 to $6 \mathrm{hr}$ before ovulation and recovered $78 \%$ of the eggs fertilized, but only $5 \%$ fertilization was recorded when less than 1000 motile epididymal spermatozoa were used. Since the discovery of the capacitation

* Postal address: 307 Huntingdon Road, Cambridge CB3 0JQ. 
phenomenon (Austin, 1951; Chang, 1951b), no study has been made of the effect on fertilization of regulating the number of spermatozoa deposited in the Fallopian tube. The present series of experiments was undertaken to compare the performance of capacitated and untreated sperm samples with reference to their fertilizing ability.

\section{MATERIALS AND METHODS}

\section{Animals and treatment}

Eighty-five female rabbits of mixed breeds were used. All does were caged separately and were left unmated for a period of 21 days before being used in an experiment. Forty does were treated with a series of six subcutaneous injections of $2 \mathrm{mg}$ of a saline suspension of acetone-extracted horse anterior pituitaries at 12-hr intervals to induce superovulation. These animals were assigned at random to experimental groups, which contained a further twenty-five does. An additional twenty oestrous does were used to provide uterine-incubated spermatozoa. Ovulation was induced by the intravenous injection of 25 i.u. HCG (Lutormone, Burroughs Wellcome) either at the time of tubal insemination when untreated spermatozoa were deposited, or 10 to $13 \mathrm{hr}$ before tubal insemination in experiments involving capacitated spermatozoa. Henceforth, it will be assumed that ovulation occurs $10 \mathrm{hr}$ after injection of HCG.

\section{Sperm recovery}

Semen was collected with an artificial vagina from six crossbred bucks of known high fertility which had not been used for at least 3 days before collection. Pooled semen samples from at least three bucks were diluted to concentrations of $1000,2000,3500,5000$ and 10,000 motile cells $/ 10 \mu \mathrm{l}$ with acidic saline (Hammond, 1949), composed of NaCl, $880 \mathrm{mg} / 100 \mathrm{ml}$; KCl, $30 \mathrm{mg} / 100 \mathrm{ml}$; $\mathrm{CaCl}_{2}, 25 \mathrm{mg} / 100 \mathrm{ml} ; \mathrm{MgCl}_{2}, 5 \mathrm{mg} / 100 \mathrm{ml} ; \mathrm{NaH}_{2} \mathrm{PO}_{4}, 10 \mathrm{mg} / 100 \mathrm{ml}$ in distilled water, to which $5 \%$ rabbit serum and $0.25 \%$ glucose had been added. These samples will be referred to as untreated spermatozoa. Spermatozoa were recovered in vivo or at autopsy from the uterine horns of does $12 \mathrm{hr}$ after mating or uterine insemination $(0.1 \mathrm{ml}$ ejaculated semen) by flushing the uterus with $5 \%$ serum acidic saline; these spermatozoa were presumed to have undergone at least partial capacitation and are referred to in this paper as capacitated spermatozoa. The capacitated sperm suspensions were brought to concentrations of $500,1500,2000,2500,5000$ or 10,000 motile cells $/ 10 \mu$ of fluid by centrifugation or dilution with $5 \%$ serum acidic saline. Final concentrations of motile spermatozoa were determined by multiple counts in a haemocytometer and checked in random samples by the nigrosin-eosin staining technique (Beatty, 1957).

\section{Tubal insemination}

Capacitated sperm samples were deposited in $10-\mu \mathrm{l}$ suspensions to a depth of 2 to $4 \mathrm{~cm}$ into the tubal ostium of thirty-four does. Twenty-four does were similarly inseminated with concentrations of untreated spermatozoa. To determine the effect of inseminate volume on fertilization, 5000 motile capaci- 
tated spermatozoa in $100 \mu \mathrm{l}$ of fluid were deposited into the tubes of two additional animals as well as the contralateral tube of four does inseminated with the same number of spermatozoa in $10 \mu \mathrm{l}$. A fourth group of five animals was tubally inseminated with 10,000 motile capacitated spermatozoa in $10 \mu \mathrm{l}$ of fluid $4 \mathrm{hr}$ before ovulation to examine the effect on fertilization of the timing of sperm deposition relative to ovulation.

\section{Egg recovery and examination}

Eggs were recovered from does either in vivo or at autopsy by flushing $2 \mathrm{ml}$ of physiological saline through the tubes 24 to $48 \mathrm{hr}$ after tubal insemination. The eggs were examined microscopically at a magnification of $\times 200$ for evidence of pronuclei or symmetrical cleavage and for sperm penetration. It was frequently impossible to determine with certainty whether a particular spermatozoon lay within the zona pellucida or only in contact with its surface. In these cases, the spermatozoon was counted as being within the zona pellucida. The total number of spermatozoa counted within both the perivitelline space and the zona pellucida is hereafter referred to as the extra spermatozoa within the egg.

\section{RESULTS}

Fertilization following tubal insemination of capacitated spermatozoa

Details of the proportion of eggs fertilized (fertilization level) relative to the concentration of capacitated spermatozoa deposited in the tubes, as well as sperm numbers in the eggs, are presented in Table 1. The variation in fertiliza-

TABLE 1

FERTILIZATION FOLLOWING DEPOSITION OF 500 TO 10,000 MOTILE CAPAGITATED SPERMATOZOA IN $10 \mu \mathrm{L}$ FLUID INTO THE FALLOPIAN TUBE 10 TO 13 HR AFTER HGG INJECTION

\begin{tabular}{r|c|c|c|c|c|c|c}
\hline $\begin{array}{c}\text { No. of } \\
\text { spermatozoa }\end{array}$ & $\begin{array}{c}\text { No. of } \\
\text { Fallopian } \\
\text { tubes }\end{array}$ & $\begin{array}{c}\text { No. of Fallopian } \\
\text { tubes with } \\
\text { fertilized eggs }\end{array}$ & $\begin{array}{c}\text { No. of } \\
\text { ovulations }\end{array}$ & $\begin{array}{c}\text { No. of } \\
\text { eggs } \\
\text { recovered }\end{array}$ & $\begin{array}{c}\text { No. of } \\
\text { eggs } \\
\text { fertilized }\end{array}$ & $\begin{array}{c}\text { Proportion } \\
\text { of eggs } \\
\text { fertilized } \\
(\%)\end{array}$ & $\begin{array}{c}\text { Mean no. of } \\
\text { sperm. . ferti- } \\
\text { lized egg* }\end{array}$ \\
\hline 500 & 17 & 6 & 147 & 145 & 24 & 16.6 & $1 \cdot 25$ \\
1500 & 12 & 8 & 99 & 88 & 29 & 33.0 & $1 \cdot 30$ \\
2000 & 9 & 7 & 134 & 129 & 88 & 68.2 & $1 \cdot 68$ \\
3500 & 5 & 5 & 57 & 48 & 35 & 72.9 & $2 \cdot 51$ \\
5000 & 11 & 9 & 130 & 124 & 76 & 61.3 & $2 \cdot 72$ \\
10,000 & 10 & 10 & 86 & 85 & 78 & $91 \cdot 8$ & 6.34 \\
\hline
\end{tabular}

* Includes the fertilizing spermatozoon and all spermatozoa counted in the perivitelline space or in contact with the zona pellucida.

tion level within each group is depicted in Text-fig. 1 and the distribution of extra spermatozoa in Text-fig. 2. Insemination of 500 motile capacitated spermatozoa in $10 \mu \mathrm{l}$ of fluid resulted in $16.6 \%$ fertilization, with $35 \%$ of the tubes yielding fertilized eggs. Following the deposition of 10,000 motile spermatozoa in $10 \mu \mathrm{l}$, fertilization occurred in every one of the Fallopian tubes examined and $91.8 \%$ of the eggs were fertilized; in $50 \%$ of the tubes in this 


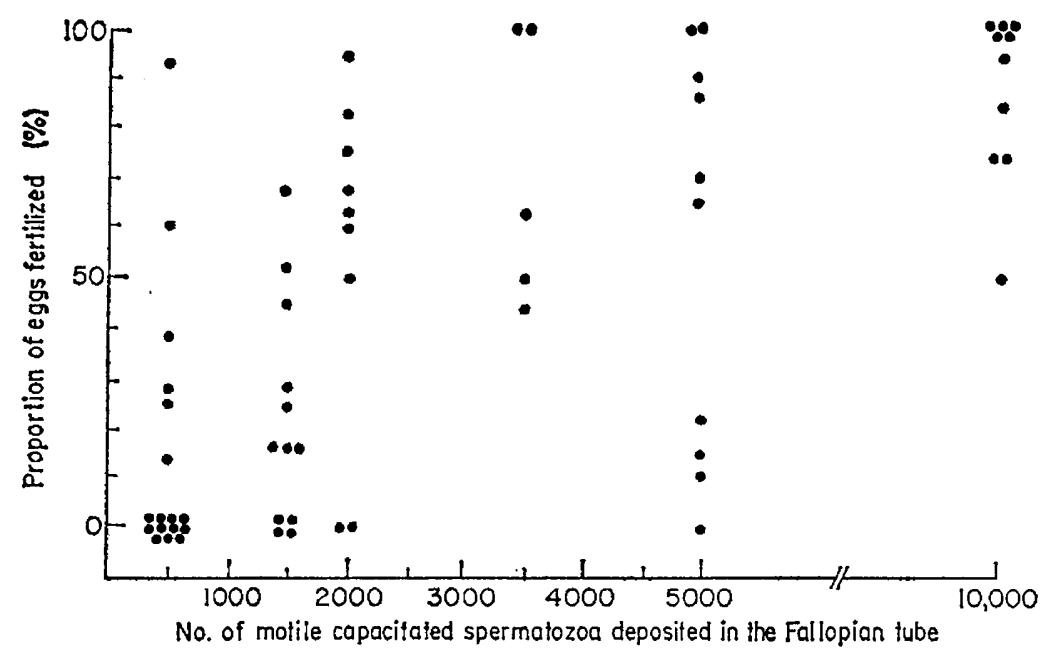

Text-Fig. 1. Distribution of fertilized eggs recovered after tubal insemination of capacitated spermatozoa 10 to $13 \mathrm{hr}$ after HCG injection. (Each dot represents one Fallopian tube.)

group, every egg was fertilized. Insemination of between 500 and 10,000 capacitated spermatozoa generally resulted in a rise in fertilization level but with wide variation at each concentration. The mean number of spermatozoa per fertilized egg increased as sperm concentration rose. The number of extra

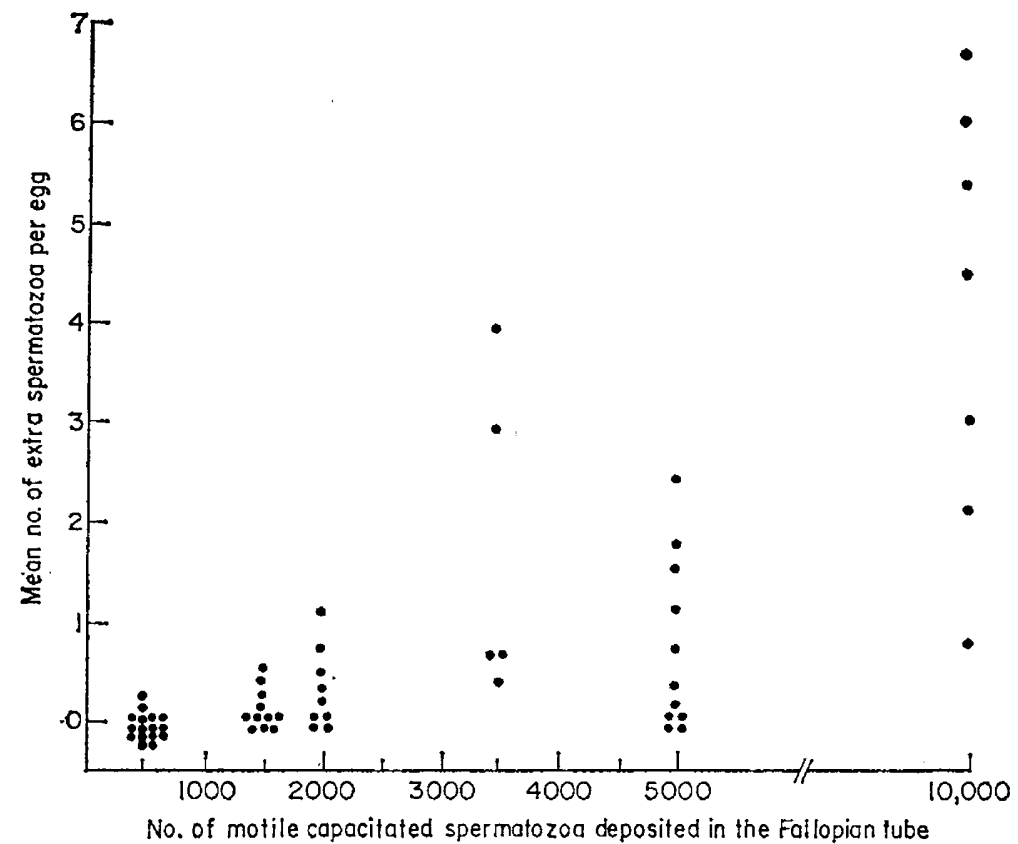

TexT-FIG. 2. Distribution of extra spermatozoa in eggs following tubal insemination of capacitated spermatozoa 10 to $13 \mathrm{hr}$ after HCG injection. (Each dot represents one Fallopian tube.) 
spermatozoa observed in eggs was variable but there was a tendency for it to increase as sperm concentrations rose. No consistent difference in fertilization level was observed between anterior pituitary-treated and untreated animals at any sperm concentration.

TABLE 2

FERTILIZATION FOLLOWING DEPOSITION OF 1000 TO 10,000 MOTILE UNTREATED SPERMATOZOA IN $10 \mu \mathrm{L}$ FLUID INTO THE FALLOPIAN TUBE AT THE TIME OF HGG INJECTION

\begin{tabular}{r|c|c|c|c|c|c|c}
\hline $\begin{array}{c}\text { No. of } \\
\text { spermatozoa }\end{array}$ & $\begin{array}{c}\text { No. of } \\
\text { Fallopian } \\
\text { tubes }\end{array}$ & $\begin{array}{c}\text { No. of Fallopian } \\
\text { tubes with } \\
\text { fertilized eggs }\end{array}$ & $\begin{array}{c}\text { No. of } \\
\text { ovulations }\end{array}$ & $\begin{array}{c}\text { No. of } \\
\text { eggs } \\
\text { recovered }\end{array}$ & $\begin{array}{c}\text { No. of } \\
\text { eggs } \\
\text { fertilized }\end{array}$ & $\begin{array}{c}\text { Proportion } \\
\text { of eggs } \\
\text { fertilized } \\
(\%)\end{array}$ & $\begin{array}{c}\text { Mean no. of } \\
\text { sperm./ferti- } \\
\text { lized egg* }\end{array}$ \\
\hline 1000 & 9 & 4 & 55 & 46 & 5 & $10 \cdot 9$ & $1 \cdot 0$ \\
2000 & 9 & 7 & 58 & 46 & 17 & $37 \cdot 0$ & $1 \cdot 65$ \\
3500 & 5 & 5 & 74 & 60 & 41 & $68 \cdot 3$ & $1 \cdot 71$ \\
5000 & 10 & 8 & 88 & 63 & 31 & $49 \cdot 2$ & 1.90 \\
10,000 & 13 & 12 & 69 & 57 & 39 & $68 \cdot 4$ & $2 \cdot 95$ \\
\hline
\end{tabular}

* Includes the fertilizing spermatozoon and all spermatozoa counted in the perivitelline space or in contact with the zona pellucida.

Fertilization following tubal insemination of untreated spermatozoa

The proportion of eggs fertilized following the tubal insemination of untreated spermatozoa $10 \mathrm{hr}$ before ovulation is presented in Table 2 and the distribution of fertilized eggs and extra spermatozoa in Text-figs. 3 and 4. With 1000 motile

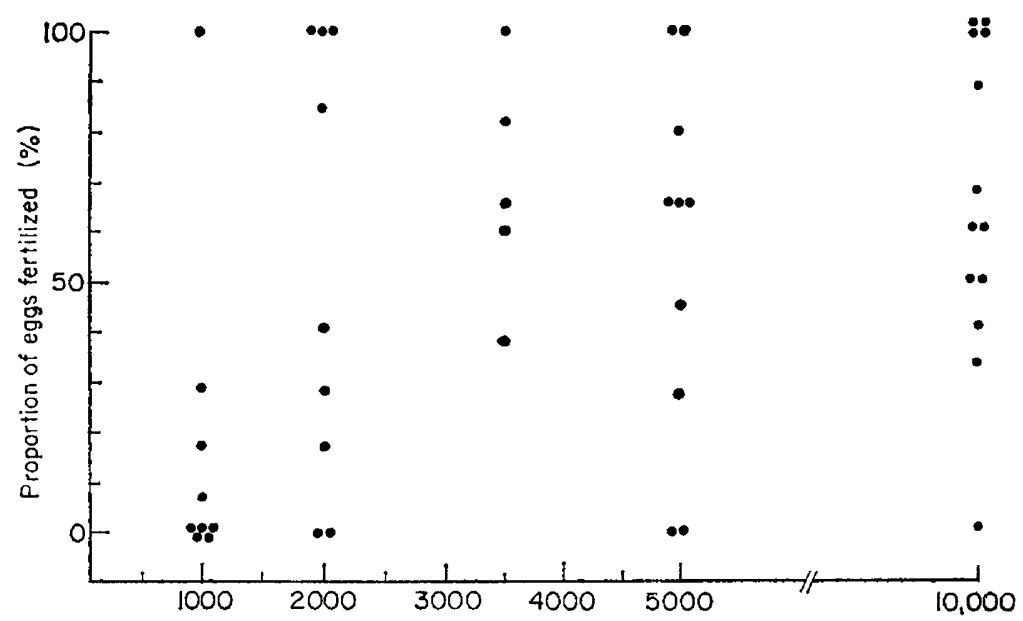

No. of motile untreated spermatozca deposited in the Fallopian fube

Text-Fig. 3. Distribution of fertilized eggs recovered following tubal insemination of untreated spermatozoa at the time of HGG injection. (Each dot represents one Fallopian tube.)

spermatozoa, fertilized eggs were recovered from $44 \%$ of the tubes and $10.9 \%$ of all eggs recovered were fertilized. In general, increasing the concentration of spermatozoa resulted in higher fertilization levels. Variation in fertility within each experimental group was wider than that observed when capacitated 


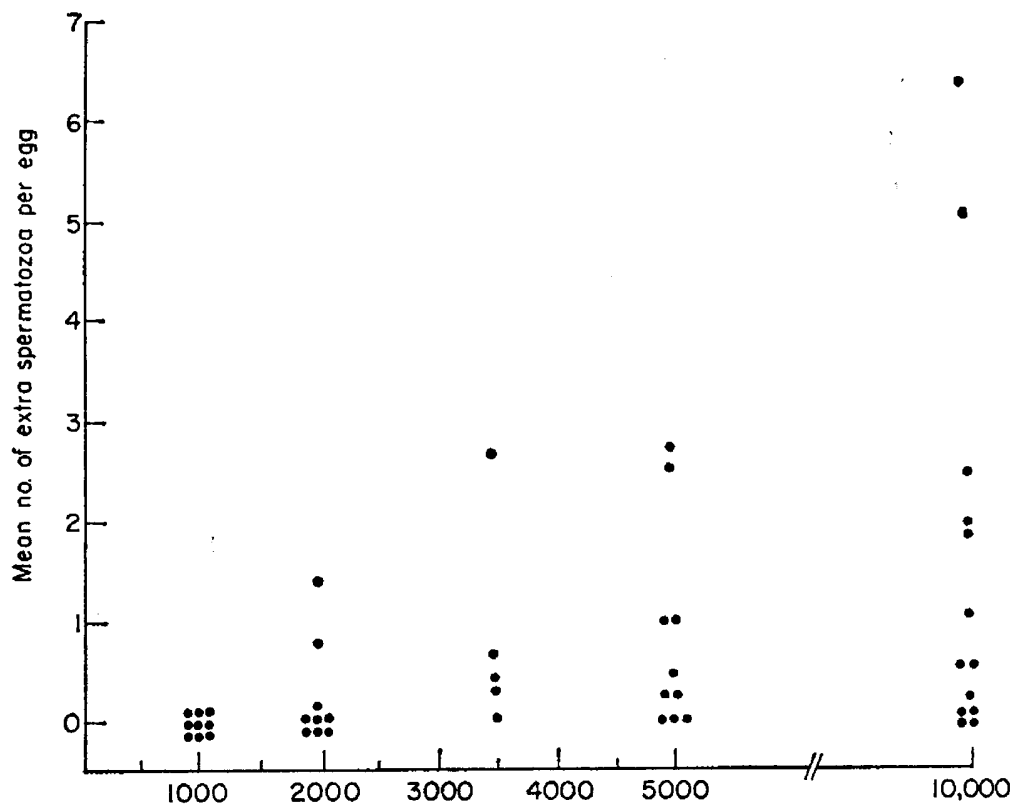

No. of motile untreated spermatozon deposited in the Follopion tube

TEXT-FIG. 4. Distribution of extra spermatozoa in eggs following tubal insemination of untreated spermatozoa at the time of HCG injection. (Each dot represents one Fallopian tube.)

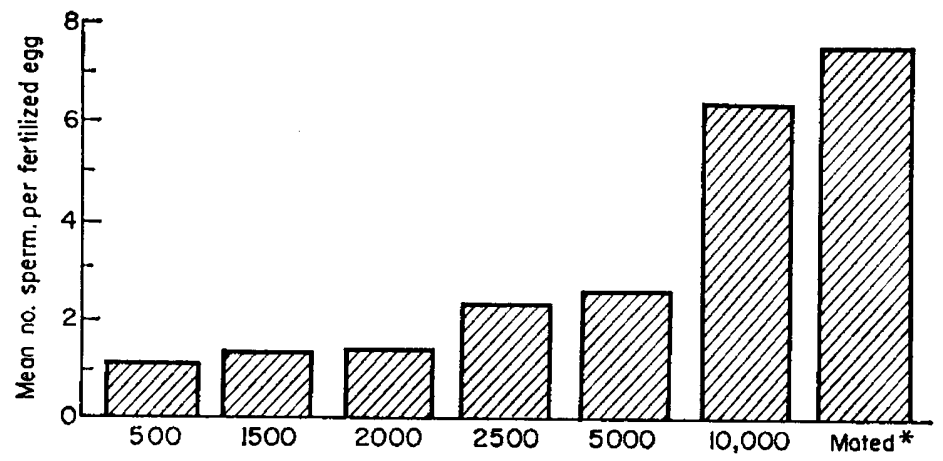

No. of capacitated spermatozoo inseminated

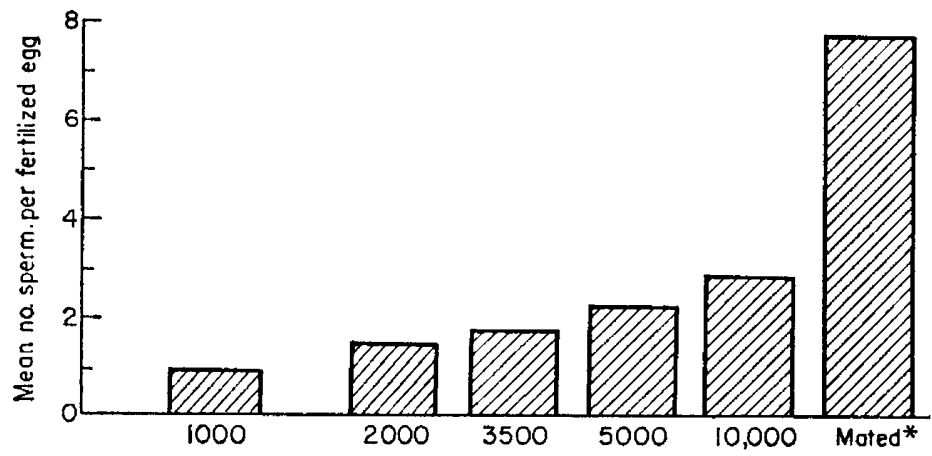

No. of untreoted spermatozon inseminated

Text-FiG. 5. Comparison of sperm numbers in the zona pellucida and perivitelline space of eggs recovered after insemination of capacitated and untreated spermatozoa.

* Data from Adams (1955). 
spermatozoa were inseminated. Thus, Fallopian tubes yielding no fertilized eggs were observed at every concentration as were tubes with maximal fertilization. A comparison of the number of spermatozoa present in eggs following deposition of capacitated or untreated sperm samples is shown in Text-fig. 5.

Fertilization in relation to inseminate volume and time of insemination

The results obtained when 5000 motile, capacitated spermatozoa were deposited either in $10 \mu \mathrm{l}$ or $100 \mu \mathrm{l}$ appears in Table 3. A higher level of fertilization was consistently observed when the same number of spermatozoa was

TABLE 3

EFFEGT OF INSEMINATE VOLUME ON FERTILIZATION FOLLOWING THE DEPOSITION OF 5000 GAPACITATED SPERMATOZOA INTO THE FALLOPIAN TUBES

\begin{tabular}{c|c|c|c|c|c|c}
\hline $\begin{array}{c}\text { Inseminate } \\
\text { volume } \\
(\mu l)\end{array}$ & $\begin{array}{c}\text { No. of } \\
\text { Fallopian } \\
\text { tubes }\end{array}$ & $\begin{array}{c}\text { No. of } \\
\text { ovulations }\end{array}$ & $\begin{array}{c}\text { No. of } \\
\text { eggs } \\
\text { recovered }\end{array}$ & $\begin{array}{c}\text { No. of } \\
\text { eggs } \\
\text { fertilized }\end{array}$ & $\begin{array}{c}\text { Proportion } \\
\text { of eggs } \\
\text { fertilized } \\
(\%)\end{array}$ & $\begin{array}{c}\text { Mean no. } \\
\text { sperm./ } \\
\text { fertilized egg }\end{array}$ \\
\hline 10 & 11 & 130 & 124 & 76 & 61.3 & $2 \cdot 67$ \\
100 & 8 & 158 & 135 & 53 & $39 \cdot 2$ & 1.11 \\
\hline
\end{tabular}

deposited in the smaller volume. There was a tendency for fewer spermatozoa to be present in eggs recovered from does receiving the more dilute suspension of spermatozoa. Table 4 shows there was little difference in fertilization level in does inseminated about the time of, or $4 \mathrm{hr}$ before, ovulation. Somewhat fewer spermatozoa were observed in eggs fertilized with spermatozoa deposited $4 \mathrm{hr}$ before ovulation.

TABLE 4

EFFECT ON FERTILIZATION OF THE TIMING OF TUBAL INSEMINATION RELATIVE TO OVULATION: 10,000 MOTILE GAPAGITATED SPERMATOZOA IN $10 \mu \mathrm{L}$ INSEMINATED

\begin{tabular}{c|c|c|c|c|c|c}
\hline $\begin{array}{c}\text { Time of } \\
\text { insemination } \\
\text { (hr after HCG) }\end{array}$ & $\begin{array}{c}\text { No. of } \\
\text { Fallopian } \\
\text { tubes }\end{array}$ & $\begin{array}{c}\text { No. of } \\
\text { ovulations }\end{array}$ & $\begin{array}{c}\text { No. of } \\
\text { eggs } \\
\text { recovered }\end{array}$ & $\begin{array}{c}\text { No. of } \\
\text { eggs } \\
\text { fertilized }\end{array}$ & $\begin{array}{c}\text { Proportion } \\
\text { of eggs } \\
\text { fertilized } \\
(\%)\end{array}$ & $\begin{array}{c}\text { Mean no. } \\
\text { sperm./ } \\
\text { fertilized egg }\end{array}$ \\
\hline 6 & 10 & 65 & 53 & 44 & 83.0 & $4 \cdot 34$ \\
10 & 10 & 86 & 85 & 78 & $91 \cdot 8$ & $6 \cdot 34$ \\
\hline
\end{tabular}

\section{DISCUSSION}

The results obtained in the present study indicate that the minimal number of spermatozoa required for fertilization in the tube is in the 500 to 1500 range. It seems unlikely that fertilization can occur when less than 500 spermatozoa are deposited, while the presence of fewer than 2000 spermatozoa generally limited fertilization to less than $50 \%$. It was necessary to increase twenty-fold the minimal concentration of capacitated spermatozoa in order to raise fertilization levels to $>90 \%$. These observations are in agreement with pre- 
viously reported results obtained under comparable conditions (Chang, 1957; Noyes, Walton \& Adams, 1958; Dukelow, Chernoff \& Williams, 1967). In contrast, when 10,000 motile, untreated spermatozoa were deposited $10 \mathrm{hr}$ before ovulation, less than $70 \%$ of the eggs were fertilized. Similarly, in previous studies the deposition of untreated spermatozoa, even in numbers greater than $1 \times 10^{6}$, has generally resulted in less than $80 \%$ of eggs being fertilized (Austin, 1948; Chang, 1951b, 1958; Adams \& Chang, 1962; Hamner \& Sojka, 1967).

By comparison with capacitated spermatozoa, fertilization levels and sperm counts were lower in all groups receiving untreated spermatozoa. This may have been due to the migration or dispersal of spermatozoa away from the site of fertilization since the untreated spermatozoa were inseminated $10 \mathrm{hr}$ earlier. However, the wide variation within each group suggests that other variables should be considered. Aliquots from an ejaculate are random samples of an unselected population. Spermatozoa designated capacitated, although not necessarily fully capacitated, have survived $12 \mathrm{hr}$ in the uterine environment. The greater variability in fertilization resulting from the insemination of comparable numbers of untreated spermatozoa may reflect variable proportions of spermatozoa in each sample capable of capacitation and subsequent fertilization. The variable fertilization levels also observed in groups inseminated with uterine spermatozoa suggest the utero-tubal junction, the ampulla and possibly the mechanism of tubal transport also have a selective effect on sperm quality. However, at least some part of the variation arises from limitations in the technique of sampling and handling small numbers of spermatozoa.

It is of interest to consider the findings of previous studies in the light of the present investigation. Braden (1953) estimated that less than 150 spermatozoa reach the site of fertilization, representing only one of every 10,000 to 100,000 spermatozoa ejaculated into the vagina. Yet Chang (1946a, b) and Wales, Martin \& O'Shea (1964) reported fertilization when less than 100,000 spermatozoa were deposited in the vagina and maximal levels with $1 \times 10^{6}$ spermatozoa. Chang (1951a) found no difference in sperm numbers in the tubes irrespective of whether $20 \times 10^{6}$ or $200 \times 10^{6}$ spermatozoa were deposited into the vagina. All of these studies are based on examination of the tract at single points in time and as such may not necessarily reflect the sperm numbers present over a period of time. Braden (1953) observed a gradual build up in sperm numbers after coitus in the various segments of the female tract to reach a state of equilibrium at $6 \mathrm{hr}$ p.c., after which sperm concentrations in the tube changed little. Since these levels were maintained over the $28 \mathrm{hr}$ period of observation, sperm movement into the tubes must have continued to offset any losses due to absorption, phagocytosis, or escape from the fimbrial ostium. Viewed over a period of time, therefore, the number of spermatozoa entering the tubes may be far greater than previous studies have suggested.

In a separate series (unpublished observations) involving ninety-five eggs examined $27 \mathrm{hr}$ p.c., the number of spermatozoa ranged from less than 5 to 500 per egg. In the present experiments, even the largest numbers of spermatozoa deposited never resulted in more than fifty spermatozoa in any egg. Austin \& Braden (1952) and Braden \& Austin (1954) suggested an important function of the female tract was to control sperm numbers at the site of fertilization and 
thus decrease the risk of polyspermy. Adams \& Chang (1962) concluded female tract restriction must be important for other reasons, since they recorded no abnormality in the number of spermatozoa in eggs even when numbers 8000 times greater than the supposed physiological levels were deposited in the tubes. By contrast, Bedford (1966) reported that the number of spermatozoa in the perivitelline space and zona pellucida of eggs recovered following the deposition of epididymal spermatozoa was often too large to allow accurate counts. Braden, Austin \& David (1954) recorded an increase in the rate of penetration of the rabbit egg over the first $6 \mathrm{hr}$ after ovulation. In the present study, when low sperm numbers were inseminated, the spermatozoa were distributed evenly in the eggs in such a manner as to suggest that a selectivity to sperm penetration may be exercised by the egg in the early post-ovulatory period. Dziuk (personal communication) considers a similar phenomenon may exist in the pig and has offered an explanation based on the position of the egg in the tube, with penetrability increasing as the egg is transported through the tube. The observation by Orgebin-Crist (1967) that fertilization is delayed following insemination of epididymal spermatozoa suggests that the high incidence of penetration observed by Bedford may have been due to late sperm penetration, and that delayed sperm capacitation and transport could facilitate the penetration of hundreds of spermatozoa under natural conditions.

No significant decrease in fertilization level was observed when capacitated spermatozoa were inseminated into the tubes $4 \mathrm{hr}$ before ovulation. This is counter to the observations by Dukelow \& Williams (1967) who reported a detrimental effect of the Fallopian tube on sperm survival and subsequent fertility.

\section{ACKNOWLEDGMENTS}

The author wishes to thank Dr C. E. Adams for his interest and support throughout the course of this work.

Acknowledgment is also made to Professor T. R. R. Mann, F.R.s., for reading and criticizing this manuscript and to $\mathrm{Mr} \mathrm{M}$. L. Norris for his excellent technical assistance. The author was supported by a Fulbright Scholarship awarded by the United States-United Kingdom Educational Commission.

\section{REFERENCES}

Adams, G. E. (1955) The frequency of occurrence of supernumerary spermatozoa in rabbit ova. Stud. Fert. 7, 130.

Adams, G. E. \& Crrang, M. C. (1962) Capacitation of rabbit spermatozoa in the fallopian tube and in the uterus. 7. $\exp$. Zool. 151, 159.

Austin, C. R. (1948) Number of sperms required for fertilization. Nature, Lond. 162, 534.

Austin, C. R. (1951) Observations on the penetration of the sperm into the mammalian egg. Aust. $\mathcal{F}$. sci. Res. Ser. B, 4, 581 .

Austin, C. R. \& Braden, A. W. H. (1952) Passage of the sperm and the penetration of the egg in mammals. Nature, Lond. 170, 919.

Beatty, R. A. (1957) Nigrosin-eosin staining of rabbit spermatozoa and the fertility of semen. Proc. $R$. Soc. Edinb. B, 67, 1, 31 .

BEDFORD, J. M. (1966) Development of the fertilizing ability of spermatozoa in the epididymis of the rabbit. 7. exp. Zool. 163, 319 .

BRADEN, A. W. H. (1953) Distribution of sperms in the genital tract of the female rabbit after coitus. Aust. 7. biol. Sci. 7, 379. 
Braden, A. W. H. \& Austin, C. R. (1954) The number of sperms about the eggs in mammals and its significance for normal fertilization. Aust. 7. biol. Sci. 7, 543.

Braden, A. W. H., Austin, C. R. \& David, H. A. (1954) The reaction of the zona pellucida to sperm penetration. Aust. F. biol. Sci. 7, 379.

Chang, M. C. (1946a) Number of spermatozoa required for fertilization of superovulated eggs in the rabbit. Fedn Proc. Fedn Am. Socs exp. Biol. 5, 11.

Ghang, M. C. (1946b) Effect of dilutions on fertilizing capacity of rabbit spermatozoa. Science, N.Y. 104, 361 .

Chang, M. C. (1951a) Fertilization in relation to the number of spermatozoa in the fallopian tubes of rabbits. Annali Ostet. Ginec., Milan, 23, 918.

Chang, M. C. (1951b) Fertilizing capacity of spermatozoa deposited into the fallopian tubes. Nature, Lond. 168, 697.

Chanc, M. C. (1957) A detrimental effect of seminal plasma on the fertilizing capacity of sperm. Nature, Lond. 179, 258.

Chang, M. G. (1958) Capacitation of rabbit spermatozoa in the uterus with special reference to the reproductive phases of the female. Endocrinology, 63, 619 .

Dukelow, W. R., Chernoff, H. N. \& Williams, W. L. (1967) Fertilizable life of the rabbit ovum relative to sperm capacitation. Am. F. Physiol. 213, 1397.

Dukelow, W. R. \& WiLliams, W. L. (1967) Survival of capacitated spermatozoa in the oviduct of the rabbit. F. Reprod. Fert. 14, 477.

Hammond, J., JR (1949) Recovery and culture of tubal mouse ova. Nature, Lond. 163, 28.

HAmner, G. E., Jones, J. P. \& Sojka, N. J. (1968) Influence of the hormonal state of the female on the fertilizing capacity of rabbit spermatozoa. Fert. Steril. 19, 137.

HamNer, C. E. \& Sojka, N. J. (1967) Capacitation of rabbit spermatozoa: species specificity and organ specificity. Proc. Soc. exp. Biol. Med. 124, 689.

Noyes, R. W., Walton, A. \& Adams, C. E. (1958) Capacitation of rabbit spermatozoa. F. Endocr. 17, 374.

Orgebin-CRIST, M. C. (1967) Maturation of spermatozoa in the rabbit epididymis: fertilizing ability and embryonic mortality in does inseminated with epididymal spermatozoa. Annls Biol. anim. Biochim. Biophys. 5, 151.

Wales, R. G., MARTIN, L. \& O'ShEA, T. (1964) Effect of dilution rate and of the number of spermatozoa inseminated on the fertility of rabbits ovulated with chorionic gonadotrophin. F. Reprod. Fert. 10,69 . 